\title{
Corporate Universities AND CORPORATION- University PARTNERSHIPS IN THAILAND: COMPLEMENTING EDUCATION IN LEARNING, LEADERSHIP AND CHANGE
}

\author{
Oliver S. Crocco $^{\mathrm{a}}$ \\ Maria Cseh \\ George Washington University \\ Dollaya Hemmapattawe \\ Siam Cement Group
}

\begin{abstract}
With an estimated workforce of 285 million and the establishment of the Association of Southeast Asian Nations (ASEAN) Economic Community in 2015, ASEAN faces vast challenges in human resource development (HRD) and higher education. These challenges in Thailand have resulted in the rise of corporate universities and corporation-university partnerships. Corporate partnerships in education adapt quickly to industry needs and are increasingly popular and complementary to traditional higher education. This research looks at one corporate university and one corporation-university partnership to investigate how, if at all, corporate universities and partnerships address HRD issues such as adult learning, leadership development, organisational change, corporate social responsibility (CSR), as well as ethical and global issues. This research finds initial evidence that corporate educational strategies address a variety of HRD issues and have the potential to revolutionise and complement higher education in Thailand in a way that drives the nation toward a more sustainable future.
\end{abstract}

Keywords: Thailand, higher education, corporate education, human resource development

\section{Introduction}

With an estimated workforce of 285 million and the establishment of the Association of Southeast Asian Nations (ASEAN) Economic Community in December 2015, ASEAN faces vast challenges in human resource development (HRD) (McLean and Chiraprapha, 2015). These challenges stem from the creation of a single market and production base as well as the free flow of skilled labour in the region as part of ASEAN economic integration (Fry, 2008). In response to these challenges, there has been a rise of corporate universities and corporation-university partnerships around the world (Abel and Li, 2012; Alagaraja and Li, 2015). Corporate involvement in education allows for quick adaptation to industry needs and is becoming increasingly widespread and complementary to traditional higher education (Allen, 2010). This makes corporate education primed to address HRD issues such as adult learning, organisational change, and leadership development. Thailand, a geographic and economic hub of mainland Southeast Asia, has shown to be a growing area for corporate universities and corporate-university partnerships (Suthiphand and Kornkarun, 2015).

In 1992, the 7th National Economic and Social Development Plan (1992-1996) of Thailand was set in motion, which led to investments in the study of HRD, including the first master's programme in HRD at the National Institute of Development Administration (NIDA) in 1992. McLean and Chiraprapha (2015) developed a taxonomy to assess a country's level of HRD education and found that Thailand

\footnotetext{
Correspondence can be directed to: olivercrocco@gwu.edu
} 
is "established" according to the taxonomy with seven universities offering a variety of programmes in HRD. While HRD-specific education in Thailand is clearly on the rise, less is known about how higher education addresses issues of learning, leadership, and change, which are essential areas in HRD.

Education that addresses issues related to learning, leadership, and change has evolved and expanded from the conventional classroom to virtual learning communities, from on-the-job training to high-technological simulation machines, and from intensive orientation programmes to pre-employment curricula (Rodriguez and Armellini, 2013). There has also been a shift away from prescriptive instruction to constructivism (Toraman and Demir, 2016). Additionally, there is a growing conviction that traditional orientations to training and workforce learning post-recruitment do not effectively develop employees' skills because of the unpredictable nature of labour markets and business expansion, especially in an emergent region such as Southeast Asia (Parry and Hayden, 2015). Parry and Hayden (2015) go on to argue for the need to identify and systematise technical skills and soft skills necessary for workers in Southeast Asia so that they are able 'to innovate and adapt to dynamic work environments' (p.76). In Thailand, some large corporate organisations such as CP ALL and Siam Cement Group (SCG) are finding ways to supply highly skilled manpower while minimising spending on training (Busaya and McLean, 2012). One solution is to establish collaborative education programmes with institutions of higher education (SCG Chemicals, 2012). These cocreative education programmes between higher education and the private sector are generating innovative and important practices in learning, leadership, and change education. Since traditional universities tend to be slower in adapting new educational demands and attitudes, understanding the role of corporate university partnerships and programmes is of increasing importance (Blass, 2005; Alagaraja and Li, 2015). There is evidence that traditional universities are not as limber in creating new programmes and adapting to new curricula, which is due in part to hierarchical and bureaucratic institutional structures (Schierenbeck, 2012). Corporations tend to be more tuned to the needs of the market with adaptable strategy and decision-making processes (Dealtry and Howard, 2008). At this time, however, little is known about corporate universities and corporationuniversity partnerships in Thailand, what corporations are operating them, and what programmes they are offering. Considering the growing need for HRD education to engage the challenges facing Thailand in ASEAN Economic Community, it is important to explore how corporate universities and corporation-university partnerships are contributing to HRD education.

This study explores the presence of corporate universities and corporation-university partnerships in Thailand and identifies how, if at all, these programmes address issues related to HRD education including, but not limited to, adult learning, leadership development, organisational change, corporate social responsibility (CSR), and ethical and global issues related to them, particularly in the context of ASEAN. Bringing together research on HRD, higher education, and corporate universities, this research explores how one corporate university program and one corporationuniversity partnership certificate programme address issues related to HRD such as adult learning, leadership development, organisational change, CSR, and ethical and global issues particularly in the context ASEAN. The researchers identified the background and curricula of one corporation-university partnership certificate programme-the Chemical Engineering Practice School (ChEPS) certificate programme, which was initiated and organised by the collaboration of Siam Cement Group (SCG), King Mongkut's University of Technology Thonburi (KMUTT), and the Suksaphat Foundation-and one corporate university master's programme in Thailand-Master of Business Administration Programme in International Business (iMBA) as part of the International Programme at the Panyapiwat Institute of Management (PIM) in Bangkok, Thailand. These programmes were selected because they represent two of the largest and most dynamic companies in Thailand, they are two of the oldest continuously running corporate educational programmes in Thailand, and they act as illustrative examples of corporate educational programmes that incorporate HRD issues in Thailand. 


\section{Methodology}

Two approaches were utilised to achieve the purpose of this study. Firstly, a concise literature and document review was conducted on the rise of corporate universities and corporation-university partnerships in Thailand. Secondly, the researchers used a multiple case study research design based on public document analysis to explore the background, curricula, and contributions of HRD of the two programmes analysed in this study. According to Merriam and Tisdell (2016), leading scholars in case study research methodology, a case study is 'an in-depth description and analysis of a bounded system' (p.37). Public documents can be 'a major source of data in qualitative research... [and] can help the researcher uncover meaning, develop understanding, and discover insights relevant to the research problem' (Merriam and Tisdell 2016, p.189). Using documents for case study research is advantageous in that they may be the best source of data to answer the research question and are unaffected by the presence of the researcher (Merriam and Tisdell, 2016). That said, Merriam and Tisdell (2016) note that document analysis is also subject to limitations such as representing ideals and goals and not necessarily reality, which are explored more in the limitations section.

This study utilises peer-reviewed journal articles and scholarly books found in the George Washington University research database including various search engines. Official websites and organisation documents were also collected and used in the analysis. Sources included publications in both Thai and English languages. Search terms included corporate university/universities, corporation-university partnerships, stakeholder university, higher education, HRD, Thailand, ASEAN, change, leadership, learning, CSR, ethical issues, global issues, and their combinations.

\section{The Corporate University, Higher Education, and HRD}

A corporate university is defined most recently in scholarly literature by Margherita and Secundo (2009) as cited by Alagaraja and Li (2015, p.22) as:

A new learning archetype which promotes and develops innovative learning and capability building processes among globally distributed and integrated networks of employees, customers, suppliers, partners, as well as academics, professionals, independent learners, and other institutions.

The trend of the corporate university has emerged primarily as the result of two factors: the fading distinction between education and training, and the gap between the goals of corporations and the offerings of universities (Blass, 2005; Alagaraja and Li, 2015). Corporate universities are generally also defined as an institution of higher learning developed by a company 'to fill a gap where the demand for company-specific training and development has not been met by the supply of education stemming from the public provision' (Blass 2005, p.62). At the heart of the corporate university is the idea that 'companies face increasing pressure today to develop outstanding human capital' (Margherita and Secundo 2011, p.176). Corporate universities began in the late1950s with internal universities in companies like General Motors and McDonald's (Margherita and Secundo, 2011), expanded into the 1980s with organisations like Disney and Motorola, and have continued to grow in popularity around the world (Blass, 2005). It is estimated that there are now around 4000 corporate universities around the world (Margherita and Secundo, 2011).

In research on Motorola University China, Shaw (2005) found that corporate universities of global companies could thrive across national boundaries, which will likely be important for ASEAN and the ASEAN Economic Community (AEC). In a study of 60 traditional universities and 40 corporate universities in the US and the UK, Walton (2005) found that corporate universities made more references to terms such as training, competitive advantage, and strategic competences, while traditional universities more often referenced scholarship, research culture, and benefiting society. Thus, corporate universities are not necessarily designed to compete with traditional higher education institutions but rather to address the needs of corporations, with special focus on change 
management, leadership, and lifelong learning (Blass, 2005). This also distinguishes corporate education initiatives from those focused on human development and poverty alleviation such as vocational and educational training (VET) discussed in Palestine by Hilal and McGrath (2016).

Over time, the idea of the corporate university has evolved from using learning as a way of supporting a company's objectives to being more interconnected with stakeholders at all levels. This has led to what Margherita and Secundo (2011) describe as the stakeholder university archetype, which is characterised by the three features of 'broad human capital development objectives... extended involvement of a wide range of stakeholders... [and] networked learning, knowledge creation, and innovation processes' (p.181). This type of integration and connection with stakeholders in education has been seen in countries like Vietnam where there is a call for university and nonuniversity stakeholders to work together in advancing medical education (Luu et al., 2009). In many ways, the context of corporate universities and corporation-university partnerships in Thailand reflects the new paradigm of the stakeholder university according to Margherita and Secundo (2011). The idea of the corporate university embedded in a nation's higher education fits well with the overarching lens of HRD.

As McLean and McLean (2001) demonstrate, national context largely influences the definition and practices of HRD in a particular nation. These include, but are not limited to influences of economics, government policy, and culture (McLean and McLean, 2001). In an attempt to write a global definition of HRD, McLean and McLean (2001, p.322) write,

Human resource development is any process or activity that, either initially or over the long term, has the potential to develop adults' work-based knowledge, expertise, productivity and satisfaction, whether for personal or group/team gain, or for the benefit of an organisation, community, nation, or ultimately, the whole of humanity.

Additionally, Ardichvili $(2012 ; 2013)$ claims that academic curricula in HRD should focus on sustainability and ethical issues, in both theory and practice. In Thailand in particular, a definition for HRD emerged in 1998 by Chartchai NaChiangmai, the founder of the first HRD program at NIDA, who wrote:

HRD is an interactive process of enhancing and facilitating the development of capabilities and potentials of individuals, organisations and communities through organisation development and community development to attain effectively, efficiently and harmoniously personal and organisation goals, as well as communal goals. (McLean and McLean 2001, p.318).

Thus, the idea of the corporate university as defined by Margherita and Secundo (2009) fits well with the goals of HRD in promoting leadership development, adult learning, and organisational change. To understand this phenomenon more fully, it is important to understand how this integration of higher education and corporate learning co-evolved in Thailand.

\section{Corporate Universities and Corporation-University Partnerships in Thailand}

The last 30 years have shown exponential growth in higher education enrolment in Thailand. During this time, Thailand reached massification, when enrolment of the relevant age group in higher education institutions was between $15 \%$ and 50\% according to Trow's (2006) framework. Recently, Thailand eclipsed 50\% enrolment in higher education institutions in 2010 (The World Bank, 2016). In the 2014 UNESCO report, "Higher Education in Asia: Expanding Out, Expanding Up," Chapman and Chien (2014, p.48) argue that Thailand is investing more in graduate education with the overarching goal 'to fuel economic development' and become a competitive educational hub in the region. To support economic development considering the $A E C$, both corporate and educational sectors are attempting to be more competitive and innovative. In one study of SCG, Parisa and Vichita (2016) 
found that concern for employees and investing in their learning was one of the driving values of the company. This has led to a rise in corporate universities as a result of economic integration in Southeast Asia as part of the AEC and increased demand for higher education in Thailand.

Examples of corporate universities in Thailand include, but are not limited to, Panyapiwat Institute of Management, founded by CP ALL, Thailand's largest publicly-traded company; Nation University, which is operated by Nation Multimedia Group which owns the daily English newspaper The Nation; Vidyasirimedhi Institute of Science and Technology (VISTEC), founded by Thailand's state-owned oil and gas company, PTT-Group; and, the Thai-Nichi Institute of Technology in Bangkok, founded the Technology Promotion Association to serve Japanese companies in the region.

Another corporate solution to increased educational needs is that of corporation-university partnerships. A prominent example of these partnerships is the Chemical Engineering Practice School (ChEPS) certificate programme, which was initiated and organised in collaboration with Siam Cement Group (SCG), King Mongkut's University of Technology Thonburi (KMUTT), and the Suksaphat Foundation. This type of partnership represents a new type of employee development in Thailand. While other partnerships are emerging with PTT Public Company Limited (PTT) and the Charoen Pokphand Group (CP) with well-known institutions of higher education in Thailand to create their own curricula, only data on the ChEPS certificate programme was available at the time of this writing. Some of these corporate universities and corporation-university partnerships are open to the public for enrolment while others are limited to existing employees. In this research, five corporate universities/corporation-university partnerships were identified and explored (see Table 1).

This increased focus on corporate involvement in higher education does not detract from the importance of public, traditional higher education but rather complements it. For example, corporate involvement is able to bring in specific content important to the workforce while traditional universities have the structure in places for theoretically and empirically informed education. Additionally, corporate universities may have different priorities in terms of knowledge production. In a mixed methods study of 12 Dutch corporate universities, results showed that while knowledge production was viewed as important by these corporate universities, concrete steps to further knowledge production was absent (Jansink et al., 2005). Ultimately, corporation-university partnerships and corporate universities can leverage educational resources. In the next two sections, a discussion of the two cases selected is presented.

\section{Siam Cement Group and King Mongkut's University of Technology Thonburi's Chemical Engineering Practice School Certificate Programme}

\section{Background}

Founded in 1913, Siam Cement Group (SCG) has expanded to include SCG Cement-Building Materials, SCG Paper, and SCG Chemicals, making it one of the largest business conglomerates in Southeast Asia. SCG was founded under a Royal Decree by King Vajiravudh (Rama VI) and is linked to Thailand's royal family through the Crown Property Bureau (CPB), which owns $30 \%$ of SCG's shares. This connection to the Thai royal family likely positively influenced the company's enduring success. SCG Chemicals, a subsidiary of SCG, manufactures and supplies chemical products throughout the region and has continually valued high levels of employee competence and ethical behaviour (SCG Chemicals, 2016).

To accomplish their vision, the Constructionism-Chemical Engineering Practice School (C-ChEPS) was established in collaboration with King Mongkut's University of Technology Thonburi (KMUTT) and the Suksaphat Foundation. Since then, the practice school has been renamed as the Chemical Engineering Practice School (ChEPS), which has expanded its corporate investors and also offers a two-year master's degree. Using the corporation-university partnership model, SCG Chemicals invested in and launched an 8-month certificate programme to provide essential training courses aligned with their organisational goals, embedded in an organisational learning culture, fully utilising knowledge and technology, and systematically monitoring what they describe as human 


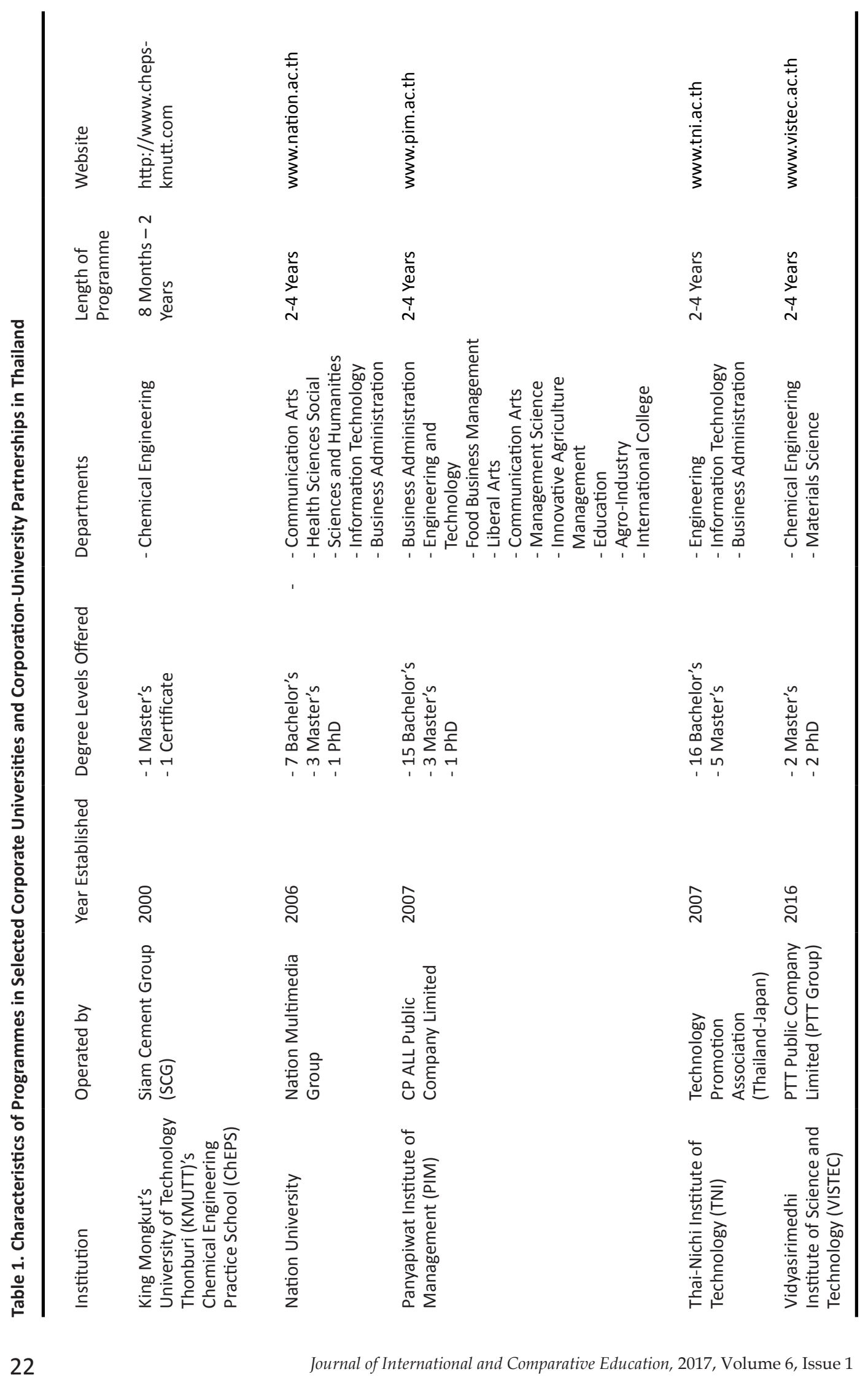


capital investment (SCG Chemicals, 2012). In this program, SCG facilitators work alongside KMUTT professors in conjunction with community members and mentors to provide a comprehensive and holistic certificate in chemical engineering. SCG is responsible to co-design the curriculum and provide manpower, time, and budget for the learning process while KMUTT is responsible for co-designing the curriculum as well as provide academic expertise in theoretical models and empirical evidence to ignite innovative ideas in the learners (SCG Chemicals, 2012).

To embed an organisational culture of lifelong learning and innovation, the first SCG Practice School was established in 2000 under the vision of Mr. Paron Isarasena Na Ayudhaya, former president of SCG (SCG Chemicals, 2012). As mentioned above, while ChEPS now runs a two-year master's programme, this paper focuses on the original C-ChEPS programme-hence referred to as the ChEPS certificate programme-designed for and offered exclusively to SCG employees with ten years of experience at SCG Chemicals. The purpose of this corporation-university certificate programme is to "increase employees' productivity and developing change agents, who will create an innovative culture in SCG Chemicals" (SCG Chemical, 2012).

\section{ChEPS Certificate Programme Curricula}

As presented in Table 2, the ChEPS certificate programme curricula consists of five modules: (a) Background Knowledge, (b) Project-based Learning, (c) Learning Tools, (d) Mindfulness, and (e) Learning Support (see Table 2).

Table 2. Characteristics of Certificate in Chemical Engineering from the Chemical Engineering Practice School (C-ChEPS) with Siam Cement Group

\begin{tabular}{|c|c|c|}
\hline Month & Module & Courses/Activities \\
\hline 1 & $\begin{array}{l}\text { Learning Tools } \\
\text { Mindfulness }\end{array}$ & $\begin{array}{l}\text { Micro Worlds and LEGO } \\
\text { Dialogue and Meditation } \\
\text { Village that learn } \\
\text { My life project }\end{array}$ \\
\hline 2 & Background Knowledge & $\begin{array}{l}\text { Pre-course (Math and Units) } \\
\text { Phase I: Chemistry }\end{array}$ \\
\hline 3 & Background Knowledge & $\begin{array}{l}\text { Phase II: Mass and energy balance } \\
\text { Phase III: Heat transfer }\end{array}$ \\
\hline 4 & Background Knowledge & $\begin{array}{l}\text { Phase IV: Fluid mechanics } \\
\text { Phase V: Separation process }\end{array}$ \\
\hline 5 & Project-based Learning & Project-Based Learning: Team project \\
\hline 6 & Learning Support & Evaluation and Idea Generation \\
\hline 7 & Project-based Learning & Project-Based Learning: Individual project \\
\hline 8 & Project-based Learning & Project-Based Learning: Individual project \\
\hline
\end{tabular}

Source: SCG Chemicals, 2012

The Background Knowledge module concentrates on technical knowledge, which includes Chemical Engineering, Mathematics, English, Computer Skills and Mechanics. Because the learners come from different educational backgrounds, this formal classroom-based training allows them to update their foundational knowledge. The KMUTT professors have the responsibility to develop tutorials based on theoretical models and empirical evidence that match SCG's goals and learner capabilities. This module is divided into four phases from basic to advanced levels. After this module, the learners understand the basics of Chemistry, Mass and Energy Balance, Fluid Mechanics, and 
Heat Transfer. In addition, the learners have a chance to visit and conduct their own experiments in the KMUTT laboratory (SCG Chemicals, 2012).

At the end of Background Knowledge module, the learners are assigned to propose projects related to their job areas. This Project-Based Learning Module provides opportunities to autonomously create, lead, and organise projects. This module is the heart of ChEPS certificate programme because it helps its participants learn how to apply the theories that they acquire from the Background Knowledge Module to real-life situations. Each learner creates one individual project and one group project. The facilitators constantly support the learners by offering practical tools, guidance on essential resources, and reflections on the progress of each learner. At the end of this second module, the learners publish their project reports and present the outcomes to their executives (SCG Chemicals, 2012).

The Learning Tools modules are incorporated throughout ChEPS certificate programme. For instance, there is a Mind Map tool that helps the learners summarise, organise, and memorise information relevant to their studies effectively. The MicroWorlds tool improves creativity, logical thinking, problem solving, and critical thinking in the learners through active participation. External experts in these fields are invited to teach the learners how to apply these tools effectively in their programme as well as in their lives (SCG Chemicals, 2012).

The Mindfulness module embeds ethical awareness in the learners. As Thailand is a largely Buddhist country, Thai leaders value mindfulness and meditation, even when it comes to chemical engineering. While rooted in Buddhism, this practice is more focused on mindfulness and not religious practice and is thus ecumenical and welcoming to those with no religious affiliation. In this module, monks from nearby temples are invited to be special facilitators. The learners spend their time learning about Buddhist principles and practices of mindfulness and meditation. This module mimics a seven-day meditation retreat at a Buddhist temple and shows learners how to meditate and practice control of their breathing. This process is believed to help the learners know themselves, reflect on ethical judgments, and build respect for one another and the world (SCG Chemicals, 2012). It also correlates with other research on the role of meditation and its relation to self-directed learning, readiness and organisational innovative ability and organisational performance (Ho, 2011). This module also relates to SCG's value of sustainability and the belief that 'competence and moral integrity are inseparable' (Siam Cement Group, 2013). In addition to meditation, the learners are trained in the SCG Code of Ethics from the SCG leaders using story-telling methods. The ChEPS certificate programme also emphasises CSR. All learners have short stays in villages to support rural communities in projects such as helping develop public facilities in those communities. These hands-on activities improve social awareness in the learners and promote the value of CSR (SCG Chemicals, 2012).

Lastly, to ensure that the learners can learn systematically, the Learning Support module is utilised throughout the certificate programme (SCG Chemicals, 2012). Facilitators and professors along with mentors, sponsors, and human resources (HR) professionals play different roles in this module. Facilitators, which consist of employees at SCG with postgraduate degrees in the Chemical Engineering field, are appointed to support, consult, and evaluate high vocational learners during the programme. Professors from KMUTT advise and respond to knowledge creation by providing academic support along with theoretical and empirical expertise. Mentors, who are comprised of Division Managers at SCG, and sponsors, who are direct managers at SCG, have duties to support and stimulate learners to achieve the programme's goals. Coordinators from the human resources department at SCG also provide learning facilities in the programme and organise activities. To evaluate the outcomes of the programme, SCG applies four criteria as individual indicators: (a) Chemical Engineering Knowledge, (b) Project-based Learning Outcomes, (c) English and Computer Knowledge, (d) Activities Participation and Learning Tools Usage (SCG Chemicals, 2012). The next section explores how the ChEPS certificate programme highlights issues related to HRD. 


\section{HRD Issues in ChEPS}

In many ways, the ChEPS certificate programme covers a wide variety of HRD issues including adult learning, organisational change, leadership, CSR, and ethical issues. The authors of this paper were not able to find aspects of the programme that directly relate to global issues or ASEAN issues. Using adult learning (Knowles, 1980), and collaborative inquiry theory (Bray et al., 2000) as a lens for analysis, the authors of this paper found that this corporation-university partnership certificate programme strongly values continued learning and collaborative problem solving.

The ChEPS certificate programme was designed by keeping a balance between formal and informal learning, which aims to develop not only Chemical Engineering skills but also soft skills in the learners (SCG Chemicals, 2012). The curriculum contains hands-on activities that relate to leadership development, organisational change, CSR, and ethical development. The curriculum is rooted in principles of constructionism, which comes from Jean Piaget's constructivism (Ackerman, 2004). The main idea of constructionism is that 'knowledge is created through cognitive interactions within social contexts' (Callahan 2007, p.79). The ChEPS certificate programme is principally focused on project-based learning and largely incorporates the principles of constructionism.

The collaborative inquiry practices (Bray et al., 2000) are applied in the group assignment in the Project-Based Learning module. Collaborative inquiry focuses on individuals learning together from their shared experiences in a systematic experiential learning cycle (Bray et al., 2000). The four phases of collaborative inquiry include forming a collaborative inquiry group, creating conditions for the group, acting on the inquiry question, and making meaning by constructing group knowledge (Bray et al., 2000).

Other HRD issues covered in depth in the ChEPS programme are CSR, business ethics, and sustainability. According to Siam Cement Group (2013), learners in the programme are consistently encouraged to focus on the principles of CSR through involvement in local communities, service learning, and mindfulness. The aforementioned mindfulness module contributes to the ideas of Yamnill, et al. (2008) who look at the contributions of Buddhism in HRD.

\section{Panyapiwat Institute of Management's Master of Business Administration (MBA) Programme in International Business}

\section{Background}

Established in 1988 by the Charoen Pokphand Group, CP ALL Public Company Limited has become the second largest company in Thailand with 35,000 employees operating over 8000 7-Eleven stores (CP ALL Public Company Limited, 2015). CP ALL is a publicly traded company run by CEO and Chairman Dhanin Chearavanont, a Thai-Chinese billionaire, along with his brothers and their families. To support its growth strategy and commitment to training, CP ALL established the Panyapiwat Institute of Management (PIM) in 2007. The primary foci of PIM are in regional and international management, retail, and technology in the public and private sectors, and to produce graduates of 'academic and moral excellence with professional ethics, sound public awareness, and a strong sense of social and environmental responsibility' (CP ALL Public Company Limited, 2015). The PIM International College was established in 2013 to respond to demands for global leadership with the motto, "AEC stance, China Connection, Global Wisdom" (Panyapiwat Institute of Management, 2013). The Master of Business Administration Programme in International Business (iMBA) at PIM is a 18-24-month graduate programme in business management with English as the language of instruction and assessment with both thesis and non-thesis options.

\section{iMBA Curriculum}

The iMBA curricula represents the global perspective of CP All Public Company Limited and consists of six courses: (a) Pre-Course, (b) Foundation Course, (c) Core Course, (d) China-ASEAN Module, (e) Elective Course, and (f) Immersion Programme (see Table 3). 
The three pre-course seminars (Global Leadership Workshop, Management, and Effective Business Communication) expose students to global perspectives and general knowledge and skills with topics on team building, problem solving, global leadership, group dynamics, public speaking, and report writing (Panyapiwat Institute of Management, 2014).

The foundation and elective courses, not unlike typical MBA programmes in Thailand, include research methods, economics, finance, marketing, and organisational behaviour. A unique contribution to this programme is its global emphasis in its core courses, which include Oriental Wisdom in Management and International Business Strategy, the latter of which includes an emphasis on ASEAN and the AEC. The China emphasis also sets it apart from other MBA programmes in Thailand. With 12 credits specifically allocated for China and ASEAN management issues.

PIM's iMBA contends that their connection to the corporate sector puts the programme in a unique place of offering instruction and work-based learning that no other university can offer. This programme prides itself in providing instructors who are 'experts in their fields' and classrooms that offer 'practical know how based on real-work situations' (Panyapiwat Institute of Management, 2016). In addition, the Immersion Programme provides learners a chance to intern in a foreign country for a month with a partner university for project development and networking. As a bonus, the PIM iMBA distinguishes itself from traditional higher education in offering high probability of employment at some capacity within CP ALL. In this sense, the iMBA programme serves as a feeder university for CP ALL's corporate workforce.

Table 3. Characteristics of Master of Business Administration Programme in International Business (iMBA) from Panyapiwat Institute of Management (PIM), CP ALL Public Company Limited

\begin{tabular}{|c|c|}
\hline Module & Courses \\
\hline Pre-Course (Non-Credit) & $\begin{array}{l}\text { Global Leadership Workshop } \\
\text { Management } \\
\text { Effective Business Communication }\end{array}$ \\
\hline Foundation Course (12 Credits) & $\begin{array}{l}\text { Economic Analysis for Business Decisions } \\
\text { Research Methodology Data Analysis } \\
\text { Financial Report \& Management } \\
\text { Marketing \& Consumer Behaviour } \\
\text { Operations Management \& Global Logistics } \\
\text { Leadership \& Organisational Behaviour }\end{array}$ \\
\hline Core Course (6 Credits) & $\begin{array}{l}\text { Oriental Wisdom in Management } \\
\text { Global Business Environment } \\
\text { International Business Strategy }\end{array}$ \\
\hline China-ASEAN Module (12 credits) & $\begin{array}{l}\text { China and AEC in Global Economy } \\
\text { Networking and Managing People in China AEC } \\
\text { Investment \& Finance in China AEC } \\
\text { Branding and Marketing in China AEC } \\
\text { Selected Topics in China Business } \\
\text { Selected Topics in ASEAN Business }\end{array}$ \\
\hline Elective Course (6 Credits) & $\begin{array}{l}\text { Managing Multinational Companies } \\
\text { Cross Cultural Communication } \\
\text { International Entrepreneurship } \\
\text { Market Entry Strategy } \\
\text { Legal Aspects in International Business } \\
\text { Selected Topics in International Business } \\
\text { Independent Study }\end{array}$ \\
\hline Immersion Programme (Optional) & Internship \\
\hline
\end{tabular}

Sources: Panyapiwat Institute of Management $(2013 ; 2014)$ 


\section{HRD Issues in PIM's iMBA}

Overall, the iMBA programme at PIM moderately addresses issues of HRD. There are only three mentions of learning in the curriculum in addition to the ideal graduate characteristic of one 'with an enquiring mind and passion for lifelong learning' (Panyapiwat Institute of Management, 2016). Global competence issues are the strength of this programme in terms of HRD and they are addressed in everything from cross-cultural communication, international business strategy, management in ASEAN and China, and international entrepreneurship. It is likely that the Chinese focus of PIM, including the fact that it has a Mandarin option MBA and PhD programme likely comes from the ethnic Chinese roots of CP All's founder.

While impressive on paper, there is no mention that these items are taught in a way that is particularly constructivist but there is a PIM strategy mentioned as 'integrating classroom and workplace learning' as well as 'work-based learning' for working students (Panyapiwat Institute of Management, 2016). Although the authors of this paper could not find any coursework that relates specifically to issues of ethics and CSR, the research team noticed that PIM has integrated these issues in their philosophy, mission, and vision, which includes mention of 'moral standard and trustworthiness' and 'partnership and contribution to the community' (Panyapiwat Institute of Management, 2016). Still, how HRD issues emerge in the program as a whole is unclear.

\section{Discussions and Limitations}

By looking at one corporate university programme (the Master of Business Administration Programme in International Business (iMBA) as part of the International Programme Panyapiwat Institute of Management in Bangkok) and one corporation-university certificate programme partnership (the Chemical Engineering Practice School (ChEPS) certificate programme, which was initiated and organised by the collaboration of Siam Cement Group (SCG) and King Mongkut's University of Technology Thonburi (KMUTT)), there is evidence that corporate universities and corporationuniversity partnerships do play a role in education in learning, leadership, and change in Thailand.

The background and curricula of these programmes show that they are a relatively recent phenomenon in Thailand (developed in the last nine years) and are adapting to the current global environment of Southeast Asia. The flexibility of these programmes in their offerings seems to imply that their corporate involvement supports adaptable learning and growth of students. Also, both programmes entail the likelihood of further employment within those corporations upon completion.

In analysing how these two programmes address issues of HRD such as adult learning, leadership development, organisational change, CSR, and ethical and global issues related to them, particularly in the context of ASEAN, it seems that both programmes address many HRD-related issues but that the ChEPS certificate programme affords more opportunities for constructionist, project-based learning. Therefore, it is likely that a programme like the ChEPS certificate programme will be more valuable in creating change-agents and adaptable leaders who are invested in their own lifelong learning. This study is limited in scope to two programmes, one corporate university programme and one corporation-university partnership certificate programme; still, this research demonstrates that HRD issues are of major concern to these programmes. The ChEPS certificate programme particularly seems on the cutting edge of integrating HRD issues in meaningful ways.

The findings of this research further reveal that these corporate educational programmes are not simply focused on organisational outcomes related to company strategies but are more broadly focused on HRD and national competitiveness within and beyond ASEAN. Hence Thai government has worked closely with the top research universities in Thailand such as KMUTT. A finding of this research is that these corporate educational initiatives may also be part of the National HRD of Thailand, which McLean (2014) shows more broadly relates to how a nation seeks to coordinate HRD from the top down. This contributes to the conversation surrounding the theory put forth by McLean and McLean (2001) that the definition and practices of HRD are shaped by context. Considering the 
role of the Thai royal family in SCG, the ethnic Chinese roots and current connections of CP All, the unique cultural, geographical, and economic context of Thailand has shaped its expression of HRD.

There is a growing paradigm shift in learning, leadership, and change education from that of limitless growth to one of sustainability and CSR (Ardichvili, 2012). This research begins to shed light on how these corporate educational collaborations provide learning opportunities for Thai professionals to develop strategies toward sustainability (Pruetipibultham, 2010). In a recent book chapter on the Sufficiency Economy Philosophy, a concept made popular in Thailand by King Bhumibol Adulyadej (Rama IX), the attitudes of moderation, reasonableness, and prudence are elevated as vital aspects to leading a nation towards sufficiency (Bergsteiner and Priyanut, 2016). This appears to be addressed in the ChEPS program but more careful examination would provide in-depth understanding how these corporate educational programmes reflect this concept along with the unique values of Thai people such as respect, honour, synergy, and learning (Somsak and Yolles, 2010).

Limitations in this study revolve primarily around the limits of document analysis as a data collection method. Since this study utilises information obtained largely from online documents and published reports, it is impossible to distinguish from the espoused values in these documents and the actual practices of the programme relying on online data collection runs the risk of missing data that may not have a strong online presence (Merriam and Tisdell, 2016). According to Yin (2014), document analysis also risks reporting bias where the organisation's ideals more than comprehensive realities are reflected in the documents. Additionally, in the case of this study, data could only be gathered about the five existing corporate universities and corporation-university partnerships, which may have left out other corporate educational programmes that do not have an online presence.

\section{Implications}

While this research begins to shed light on the ways these types of corporate-oriented programmes elucidate HRD issues, there are implications for further research. For example, deepening this case study to include in-depth interviews with professors, corporate university founders, and partners would help further understand how the corporate programme is administered, the quality of the modules, and the perspectives of stakeholders. Another implication for further research would revolve around a longitudinal study of these programmes and the way their alumni practice HRD. Similar to those suggested by Pang (1982), tracer studies could follow alumni of these programs through participant observation and interviews to examine their success in the labour market and how they integrate HRD issues in their lives and work. Additionally, this study implies that further research into understanding some of the barriers and facilitators in these types of partnerships in Southeast Asia would be helpful in the design and implementation of future programmes. Also, the investigation of how Buddhist philosophy influences HRD initiatives in Thai higher education and collaboration with corporations, especially with relation to sustainability and business ethics.

This research supports private sector organisations interested in learning, leadership, and change education that do not currently have their own pre-employment academic programmes or certificate programmes to collaborate with existing institutes of higher education. Future research could look at how these corporate programmes may promote customisability of the programmes to the unique Thai context. For example, in a study of culturally endorsed leadership styles of Thai employees, Vimolwan (2010) found that consultative leadership styles were preferred, which led employees to perceive a role in decision-making processes and in turn increased job satisfaction. Therefore, future studies could look at corporate educational programmes that utilise consultative leadership styles to support learning and leadership development.

\section{Conclusion}

An evolving blend of corporate educational models is on the rise in the Thai context, and these programs are addressing a variety of HRD issues. From the broad educational needs of the largest 
conglomerates to the specific training goals of a division like SCG Chemicals, these corporate universities and corporation-university partnerships are addressing crucial needs for adult learning, leadership development, and organizational change. In times of political or societal change, corporate partnerships in education can alleviate financial burdens and make significant contributions to the higher education landscape. Further exploration of the role of corporate educational programs in Thailand will help researchers and practitioners understand how these institutions and partnerships are preparing future change agents and shaping Thailand's unique expression of HRD considering its cultural, geographical, and economic context towards a more sustainable future. Furthermore, it is reasonable to infer that these corporate educational programs will continue to play a vital role in Thai society as a whole in bringing about the vision of the late King Bhumibol of a sufficiency economy.

\section{References}

Abel, A. and Li, J. (2012). Exploring the corporate university phenomenon: Development and implementation of a comprehensive survey. Human Resource Development Quarterly, 23 (1), pp. 103-128.

Ackerman, E. (2004). Constructing knowledge and transforming the world. In M. Tokoro and L. Steels (Eds.), A Learning Zone of One's Own: Sharing Representations and Flow in Collaborative Learning Environments. Washington, DC: IOS Press, pp. 15-37.

Alagaraja, M. and Li, J. (2015). Utilizing institutional perspectives to investigate the emergence, rise, and (relative) decline of corporate universities. Human Resource Development International, 18(1), pp. 4-23.

Allen, M. (2002). The Corporate University Handbook: Designing, managing, and growing a successful program. New York: AMACOM.

Allen, M. (2010). Corporate universities 2010: Globalization and greater sophistication. Journal of International Management Studies, 5(1), pp. 48-53.

Ardichvili, A. (2012). Sustainability or limitless expansion: Paradigm shift in HRD practice and teaching. European Journal of Training and Development, 36(9), pp. 873-887.

Ardichvili, A. (2013). The role of HRD in CSR, sustainability, and ethics: A relational model. Human Resource Development Review, 12(4), pp. 456-473.

Association of Southeast Asian Nations. (2015). ASEAN Economic Community Blueprint 2025. Available at http://www.asean.org/storage/2016/03/AECBP_2025r_FINAL.pdf [Accessed 19 December 2016].

Bergsteiner, H. and Priyanut D. (2016). The sufficiency economy philosophy process. In G. C. Avery and H. Bergsteiner (Eds.), Sufficiency Thinking: Thailand's Gift to an Unsustainable World. Sydney: Allen \& Unwin, pp. 32-52.

Blass, E. (2005). The rise of the corporate university. Journal of European Industrial Training, 29(1), pp. 58-74.

Bray, J., Lee, J., Smith, L. and Yorks, L. (2000). Collaborative Inquiry in Practice: Action, reflection and making meaning. Thousand Oaks, CA: Sage Publications.

Busaya, V. and McLean, G. N. (2012). Leadership development in selected leading Thai companies. Journal of Leadership Studies, 6(1), pp. 6-22.

Callahan, J. L. (2007). Gazing into the crystal ball: Critical HRD as a future of research in the field. Human Resource Development International, 10(1), pp. 77-82.

Chapman, D. and Chien, C. (2014). Expanding out and up: What are the system-level dynamics? Case study of Malaysia and Thailand. In D. Chapman and C. Chien (Eds.), Higher Education in Asia: Expanding Out, Expanding Up. Montreal: UNESCO Institute for Statistics.

CP All Public Company Limited. (2015). CP All Annual Report 2014. Available at http://www.cpall. co.th/annualreport2014/pdf/CPAll_2014.pdf [Accessed 19 December 2016].

Dealtry, R. and Howard, K. (2008). Moving towards optimising demand-led learning. Journal of Workplace Learning, 20(3), pp. 214-224. 
Fry, G. (2008). The Association of Southeast Asian Nations. New York: Infobase Publishing.

Hellriegel, D. and Slocum, J. (2011). Organizational Behavior (13 ${ }^{\text {th }}$ edition). Mason, OH: SouthWestern Cengage Learning.

Hilal, R. and McGrath, S. (2016). The role of vocational education and training in Palestine in addressing inequality and promoting human development. Journal of International and Comparative Education, 5(2), pp. 87-102.

Ho, L. (2011). Meditation, learning, organizational innovation and performance. Industrial Management \& Data Systems, 111(1), pp. 113-131.

Jansink, F., Kwakman, K. and Streumer, J. (2005). The knowledge-productive corporate university. Journal of European Industrial Training, 29(1), pp. 40-57.

Knowles, M. S. (1980). The Modern Practice of Adult Education: From pedagogy to andragogy (2 ${ }^{\text {nd }}$ edition). New York: Cambridge Books.

Luu, N. H., Nguyen, L. V., Wilt, G. J., Broerse, J., Ruitenberg, E. J. and Wright, E. P. (2009). Motivation of university and non-university stakeholders to change medical education in Vietnam. BMC Medical Education, 9(49), pp. 1-14.

Margherita, A. and Secundo, G. (2009). The emergence of the stakeholder university. In A. Romano (Ed.), Open Business Innovation Leadership: The Emergence of the Stakeholder University. London: Palgrave Macmillan, pp. 170-207.

Margherita, A. and Secundo, G. (2011). The stakeholder university as learning model of the extended enterprise. Journal of Management Development, 30(2), pp. 175-186.

McLean, G. N. (2014). National HRD. In. N. E. Chalofsky, T. S. Rocco and M. L. Morris (Eds.), Handbook of Human Resource Development. Hoboken, NJ: John Wiley \& Sons, pp. 643-660.

McLean, G. N. and Chiraprapha T. A. (2015). HRD education in developing countries. Advances in Developing Human Resources, 17(2), pp. 213-238.

McLean, G. N. and McLean, L. (2001). If we can't define HRD in one country, how can we define it in an international context? Human Resource Development International, 4(3), pp. 313-326.

Merriam, S. B., Caffarella, R. S. and Baumgartner, L. M. (2006). Learning in Adulthood: A comprehensive guide ( $3^{\text {rd }}$ edition). San Francisco, CA: Jossey-Bass.

Merriam, S. B. and Tisdell, E. J. (2016). Qualitative Research: A guide to design and implementation ( $5^{\text {th }}$ edition). San Francisco, CA: Jossey-Bass.

Oranuch, P. (2010). The sufficiency economy philosophy and strategic HRD: A sustainable development for Thailand. Human Resource Development International, 13(1), pp. 99-110.

Pang, E. F. (1982). Education, Manpower, and Development in Singapore. Singapore: NUS Press.

Panyapiwat Institute of Management. (2013). Master of Business Administration Program in International Business. Available at http://interprogram.pim.ac.th/pages/imba [Accessed 19 December 2016].

Panyapiwat Institute of Management. (2014). iMBA Course Description. Available at http:// interprogram.pim.ac.th/uploads/content/2014/12/o_198n3lsk41lva1on11m591f92fnda.pdf [Accessed 19 December 2016].

Panyapiwat Institute of Management. (2016). About Us. Available at http://interprogram.pim.ac.th/ en/pages/about-us [Accessed 21 December 2016].

Parisa, R. and Vichita, V. R. (2016). Siam cement group as a sustainable enterprise. In G. C. Avery and H. Bergsteiner (Eds.), Sufficiency Thinking: Thailand's Gift to an Unsustainable World. Sydney: Allen \& Unwin, pp. 198-215.

Parry, J. and Hayden, M. (2015). Skills development: A review with reference to Southeast Asia. Journal of International and Comparative Education, 4(2), pp. 67-78.

Pruetipibultham, O. (2010). The sufficiency economy philosophy and strategic HRD: A sustainable development for Thailand. Human Resource Development International, 13(1), pp. 99-110.

Rodriguez, B. C. P. and Armellini, A. (2013). Interaction and effectiveness of corporate e-learning programmes. Human Resource Development International, 16(4), pp. 480-489. 
SCG Chemicals. (2012). Constructionism-Chemical Engineering Practice School (C-ChEPS): Summary report 2012. Bangkok: SCG Chemicals.

SCG Chemicals. (2016). Company at a Glance: Overview. Available at https://www.scgchemicals. com/en/company/company-at-a-glance/overview [Accessed 23 December 2016].

Schierenbeck, C. (2012). Fixing Higher Education: A business manager's take on how to boost productivity in higher education. Wiesbaden: Springer Fachmedien Wiesbaden.

Shaw, S. (2005). The corporate university: Global or local phenomenon? Journal of European Industrial Training, 29(1), pp. 21-39.

Siam Cement Group. (2013). SCG Sustainability Report 2013. Available at http://www.scg.co.th/ en/05sustainability_development/03_sustainability_report.html [Accessed 19 December 2016].

Siriporn, Y., McLean, G. N. and Pagorn S. (2008). The role of a religious institution in HRD: The case of Wat (temple) Panyanataram, Thailand. Human Resource Development International, 11(3), pp. 223-235.

Somsak, J. and Yolles, M. (2010). Assessing values and value change in Thai organizations. Journal of Organisational Transformation \& Social Change, 7(3), pp. 321-347.

Suthiphand, C. and Kornkarun, C. (2015). Thailand's Economic Integration with Neighboring Countries and Possible Connectivity with South Asia. ADBI Working Paper 520. Tokyo: Asian Development Bank Institute. Available at http://www.adbi.org/working- paper/2015/04/03/6589.thailand. economic.integration/ [Accessed 29 January 2017].

The World Bank. (2016). Thailand. Available at http://data.worldbank.org/country/thailand [Accessed 19 December 2016].

Trow, M. (2006). Reflections on the transition from elite to mass to universal access: Forms and phases of higher education in modern societies since WWII. In J. F. Forest and P G. Altbach (Eds.), International Handbook of Higher Education. Dordrecht: Springer, pp. 243- 280.

Toraman, C. and Demir, E. (2016). The effect of constructivism on attitudes towards lessons: A metaanalysis study. Eurasian Journal of Educational Research, 62(62), pp. 115-142.

Vimolwan, Y. (2010). A study of Thai employees' preferred leadership style. Asia Pacific Business Review, 16(1-2), pp. 161-181.

Visser, W. (2007). The A to Z of Corporate Social Responsibility: A complete reference guide to concepts, codes and organisations. Chichester, England: John Wiley \& Sons.

Walton, J. (2005). Would the real corporate university please stand up? Journal of European Industrial Training, 29(1), pp. 7-20.

Yamnill, S., McLean, G. N. and Singsuriya, P. (2008). The role of a religious institution in HRD: The case of Wat (temple) Panyanantaram, Thailand. Human Resource Development International, 11(3), pp. 223-235.

Yin, R. (2014). Case Study Research: Design and methods ( $5^{\text {th }}$ edition). Los Angeles, CA: Sage. 
